\title{
構造物を支持する剛体リンクの配置適正化による入カパワー低減
}

\author{
高阪 文彦 $* 1$, 井上 剛志 $* 2$, 高木 賢太郎 $* 2$
}

\section{Reduction of input power to the structure \\ by the configuration of supporting rigid link mechanics}

\author{
Fumihiko KOSAKA ${ }^{* 1}$, Tsuyoshi INOUE ${ }^{* 2}$ and Kentaro TAKAGI ${ }^{* 2}$ \\ *1 Mitsubishi Motors Corporation \\ 1 Nakashinkiri, Hashime-cho, Okazaki-shi, Aichi 444-8501, Japan \\ *2 Dept. of Mechanical Science and Engineering, Nagoya University \\ Furo-cho, Chikusa-ku, Nagoya 464-8603, Japan
}

\section{Received 8 June 2014}

\begin{abstract}
Suspension of a vehicle plays an important role on the vibration insulation mechanism for reducing the structure born road noise. Using a low stiffness suspension bush is one of the typical countermeasure for the vibration insulation, but such a countermeasure makes the driving stability and the handling comfort worse. The suspension design which achieves the both performance at high level is required in the automotive industry these day. As one of the possible way to achieve the requirement, the road noise reduction by the suspension geometry which has not been investigated so far is presented in this paper. For simplicity, the two dimensional simple model considering a multi-link suspension which consists of the rigid links as suspension and the simply supported elastic beam as body is used. The motion of the suspension forms the energy flow from the road surface to the vehicle body to which the suspension is connected at multiple points. The energy flow which doesn't supply power to the vehicle body is found by the shape optimization based on the sensitivity analysis with respect to the suspension geometry. The shape optimization result shows maximized negative input power contribution at frequencies of interest. And the energy flow change is done by making the particular mode hardly resonant by having node of its mode shape at the excitation point. Moreover, the effect of the mode shape change appears as input power reduction at other frequency range. These effects are analysed by input power modal expansion.
\end{abstract}

Key words : Vibration insulation, Energy flow, Power balance, Sensitivity analysis, Shape optimization

\section{1. 緒言}

自動車のロードノイズは，路面からの入力がタイヤ，サスペンションを伝わり，車体を振動させ音となるメカニ ズムである。したがって，サスペンションにおける防振設計はロードノイズ低減において重要な役割を果たして いる，ロードーノイズ低減方法としては，単純なマス-バネ系を考えた強制変位振動に対する防振理論に基づくサ スペンションブッシュの低剛性化や二重防振化が用いられているが，一般的には，そのような対策は操縦安定性 を損なうため, 静肃性と操縦安定性を両立したサスペンションの設計は難しく，その両立を達成できるような新た な設計方法が求められている.

これまでのサスペンションの構造に関する研究としては，城戸ら（城戸，末岡，2005）による分系間の連成を

No.14-00306 [DOI: 10.1299/transjsme.2014dr0331]

${ }^{* 1}$ 正員, 三菱自動車工業 (株) (厂444-8501 愛知県岡崎市橋目町中新切 1)

*2 正員, 名古屋大学工学研究科（广464-8603 愛知県名古屋市千種区不老町）

E-mail of corresponding author: fumihiko.kosaka@mitsubishi-motors.com 
定量的に扱う指標による検討方法，池澤ら（池澤，吉村，2008）によるサスペンションの固有值に関する感度解 析などが行われている。しかし， サスペンションジオメトリ変更によるロードノイズ低減については今まで報告 されておらず，静肃性と操縦安定性の両立に関して有益な知見が得られる可能性があるそそこで，本論文では，サ スペンションジオメトリによるロードノイズ低減に注目する.

サスペンションブッシュの低剛性化は振動絶縁によるロードノイズ低減であるのに対し，サスペンションジオ メトリ変更によるロードノイズ低減は, 系の運動を変えることによるエネルギーフロー変更であると考えること ができる，そこで，本論文では，サスペンションジオメトリ変更によるエネルギーフローの変化に着目をするた め，ロードノイズ評価として車体への入力パワーを用いる. なお，車体への入力パワーは，パワーバランスの観 点より，車室内の統計的な空間平均音圧レベルと比例することが知られており（門松，岩永，2002），車室内音響 モードによる影響を排除した形のロードノイズを評価することと等しい.

本論文では，サスペンションジオメトリによるロードノイズ低減をリアマルチリンクサスペンションを想定し た簡易モデルを用いて検討する. まず，2 章において簡易モデルを示し，3 章において車体への入力パワーを導出 し, サスペンションリンクの結合点位置に関する入力パワーの一次感度を求める. 4 章にて 3 章で求めた感度を用 いた形状最適化を行い, その結果について考察を行う.

\section{2. 解 析 モ デル}

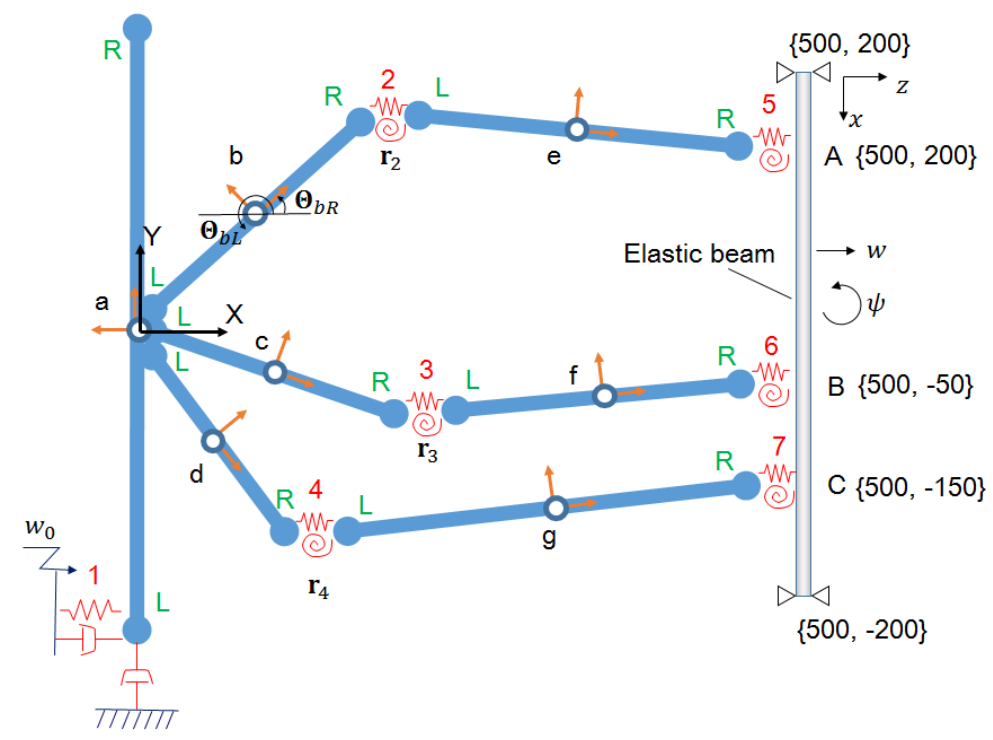

Fig. 1 Model considering multi-link suspension and structure: Wheel is modeled by link a. Knuckle is modeled by links $\mathrm{b}$ to $\mathrm{d}$. Upper arm, toe control arm and lower arm are modeled by link e, $\mathrm{f}$ and $\mathrm{g}$, respectively. Vehicle body is modeled by simply supperted beam. Link a, b, c and d are rigidly conneted at center of gravity of link a. The others are connected by translational and rotational spring.

図 1 に示す $\mathrm{a} \sim \mathrm{g}$ の剛体リンクと弾性梁からなるマルチリンクサスペンションを想定したモデルを考える. 剛体 リンクはホイール, ハブ, ナックル, サスペンションアームを想定し, 弾性梁はサブフレーム, 車体を想定してい る.それぞれのリンクはその中央に重心を持ち, リンク b , c , d はその L 端でリンク a の重心と固定される.リン ク e, f, g はその L 端でそれぞれリンク b, c, d と, R 端で弾性梁の結合点 $\mathrm{A}, \mathrm{B}, \mathrm{C}$ とサスペンションブッシュ を想定した並進バネおよび回転バネで結合されている. 弾性梁は簡単のため両端単純支持とする. 入力は路面に より強制変位されるタイヤを想定し，片端がリンク a の L 端につけられたバネと減衰要素の他端を $X$ 方向に変位 $w_{0}$ で強制変位する. サスペンションジオメトリ変更による入力パワー低減を目的とするため, 剛体リンクの結合 点のバネ剛性は変えず，結合点の位置ベクトル $\mathbf{r}_{i}(i=2,3,4)$ を変更して入力パワー低減を行う.

リンク $\mathrm{a}$ は長さ $l_{a}=600[\mathrm{~mm}]$, 単位長さあたりの質量は $m_{a}=5.1[\mathrm{~kg} / \mathrm{m}]$, リンク $\mathrm{b} \sim \mathrm{d}$ の単位長さあたりの質 量は $m_{b} \sim m_{d}=2.1[\mathrm{~kg} / \mathrm{m}]$, リンク $\mathrm{e} \sim \mathrm{g}$ の単位長さあたりの質量は $m_{e} \sim m_{g}=1.7[\mathrm{~kg} / \mathrm{m}]$ とした. バネ 1 の並進 
バネ剛性を $k_{1}=200[\mathrm{~N} / \mathrm{mm}]$, 減衰要素 1 の並進方向に関する減衰を $c=0.1[\mathrm{Ns} / \mathrm{mm}]$ とし, バネ 2 7 の並進バ 市剛性を $k_{2} \sim k_{7}=1.5 \times 10^{4}[\mathrm{~N} / \mathrm{mm}]$, 回転バネ剛性を $k_{\theta 2} \sim k_{\theta 7}=3.0 \times 10^{5}[\mathrm{Nmm} / \mathrm{rad}]$ とした. 弾性梁はヤング率 $E=2.1 \times 10^{11}[\mathrm{~Pa}]$, 密度 $\rho=7860\left[\mathrm{~kg} / \mathrm{m}^{3}\right], x$ 方向に長さ $L=400[\mathrm{~mm}], z$ 方向に厚さ $h=10[\mathrm{~mm}]$, 紙面奥行 き方向に幅 $b=50[\mathrm{~mm}]$, モーダル減衰係数は全てのモードで同じとし $\eta=0.04$ とする. リンクの初期配置は, $\mathbf{r}_{2}=\{200,130\}[\mathrm{mm}], \mathbf{r}_{3}=\{250,-60\}[\mathrm{mm}], \mathbf{r}_{4}=\{120,-110\}[\mathrm{mm}]$ である.

リンクの変位ベクトルをリンクの重心, $\mathrm{L}$ 端, $\mathrm{R}$ 端にとり, それぞれの変位ベクトルは $X, Y$ 方向の並進変位 $u, v$, 回転変位 $\boldsymbol{\theta}$ の成分を持つ. リンク $\mathrm{a}$ の変位ベクトル $\mathbf{q}_{a}$ を例にとると次式となる.

$$
\begin{aligned}
& \mathbf{q}_{a}=\left\{\mathbf{u}_{a o}^{T} \mathbf{u}_{a L}^{T} \mathbf{u}_{a R}^{T}\right\}^{T} \\
& \mathbf{u}_{a k}=\left\{u_{a k} v_{a k} \theta_{a k}\right\}^{T}, \quad k=o, L, R
\end{aligned}
$$

添え字の $o$ は重心， $L, R$ はそれぞれ $\mathrm{L}$ 端， $\mathrm{R}$ 端を表す. 他のリンクについても同様に行い，全てのリンクの変位 ベクトル $\mathbf{q}$ を次式のように表す.

$$
\mathbf{q}=\left\{\mathbf{q}_{a}^{T} \cdots \mathbf{q}_{g}^{T}\right\}^{T}
$$

弾性梁の変位はモーダル座標系で考える. 弾性梁の $z$ 方向たわみ変位 $w$, 回転変位 $\psi$ をモード座標で以下のよう に表す。

$$
\begin{aligned}
& w=\sum_{r} \phi_{w r} \xi_{r} \\
& \psi=\sum_{r} \phi_{\psi r} \xi_{r}
\end{aligned}
$$

$\xi_{r}$ は $r$ 次モードのモード振幅, $\phi_{w r}, \phi_{\psi r}$ は $r$ 次モードの並進, 回転方向のモード形状であり, 両端単純支持の梁 では次式である。

$$
\begin{aligned}
& \phi_{w r}(x)=\sin \frac{r \pi x}{L} \\
& \phi_{\psi r}(x)=\frac{r \pi}{L} \cos \frac{r \pi x}{L}
\end{aligned}
$$

以降の章で用いるモード変位ベクトル $\boldsymbol{\xi}$ を下のように定義する.

$$
\boldsymbol{\xi}=\left\{\xi_{1} \xi_{2} \ldots\right\}^{T}
$$

\section{3. 弾性構造物への入カパワーと感度}

\section{$3 \cdot 1$ 剛体リンク要素}

剛体リンクの独立変数と従属変数の関係をリンク $\mathrm{a}$ を例にとり示す. 剛体リンクの重心と両端の回転変位は等し いため次式が成り立つ.

$$
\theta_{a o}=\theta_{a L}=\theta_{a R}
$$

また，重心位置が変位した際の $\mathrm{L}$ 端， $\mathrm{R}$ 端の並進方向変位は，回転変位が微小であるとすると幾何学的条件より， リンク $\mathrm{a} の$ 重心からの $\mathrm{L}$ 端の回転姿勢 $\Theta_{a L}, \mathrm{R}$ 端の回転姿勢 $\Theta_{a R}$, 重心からの $\mathrm{L}$ 端, $\mathrm{R}$ 端のへの長さ $l_{a L}, l_{a R}$ を用 いて次のように表される。

$$
\begin{aligned}
& \left\{\begin{array}{l}
u_{a L} \\
v_{a L}
\end{array}\right\}=\left\{\begin{array}{l}
u_{a o} \\
v_{a o}
\end{array}\right\}+\left\{\begin{array}{c}
-\theta_{a o} l_{a L} \sin \Theta_{a L} \\
\theta_{a o} l_{a L} \cos \Theta_{a L}
\end{array}\right\} \\
& \left\{\begin{array}{l}
u_{a R} \\
v_{a R}
\end{array}\right\}=\left\{\begin{array}{l}
u_{a o} \\
v_{a o}
\end{array}\right\}+\left\{\begin{array}{c}
-\theta_{a o} l_{a R} \sin \Theta_{a R} \\
\theta_{a o} l_{a R} \cos \Theta_{a R}
\end{array}\right\}
\end{aligned}
$$


式(9)(10)(11)より, 以下の関係が導かれる.

$$
\begin{gathered}
\left\{\begin{array}{l}
\mathbf{u}_{a o} \\
\mathbf{u}_{a L} \\
\mathbf{u}_{a R}
\end{array}\right\}=\left[\begin{array}{c}
\mathbf{I} \\
\boldsymbol{\beta}_{a}
\end{array}\right] \mathbf{u}_{a o} \\
\boldsymbol{\beta}_{a}=\left[\begin{array}{ccc}
1 & 0 & -l_{a L} \sin \Theta_{a L} \\
0 & 1 & l_{a L} \cos \Theta_{a L} \\
0 & 0 & 1 \\
1 & 0 & -l_{a R} \sin \Theta_{a R} \\
0 & 1 & l_{a R} \cos \Theta_{a R} \\
0 & 0 & 1
\end{array}\right]
\end{gathered}
$$

ここで, $\mathbf{I}$ は $3 \times 3$ の単位行列である，以上のように，剛体リンクの両端の変位は，重心位置の変位とリンクの初 期姿勢の関数として表される. 全てのリンクに対して適用寸ると, 剛体リンクの変位ベクトル $\mathbf{q}$ が以下のように 表される.

$$
\begin{aligned}
& \mathbf{q}=\boldsymbol{\beta} \mathbf{q}_{o}
\end{aligned}
$$

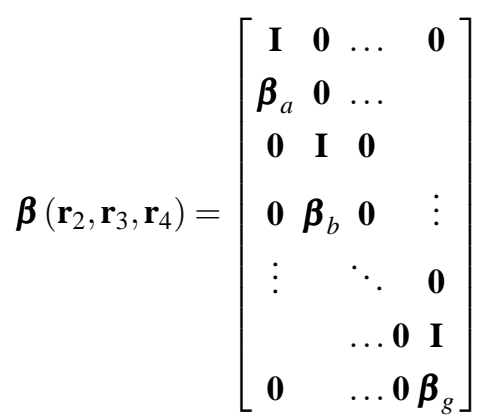

$$
\begin{aligned}
& \mathbf{q}_{o}=\left\{\mathbf{u}_{a o}^{T} \cdots \mathbf{u}_{g o}^{T}\right\}^{T}
\end{aligned}
$$

剛体リンクの長さ, 回転姿勢が結合点位置 $\mathbf{r}_{i}(i=2,3,4)$ の関数であるため, $\boldsymbol{\beta}$ は結合点位置の関数となる.

\section{$3 \cdot 2$ 運動方程式}

点 $\mathrm{A}$ における並進バネによる反力 $f_{A}$, 回転バネによる反力 $M_{A}$ は式 (4)(5)より以下のように表される.

$$
\left.\begin{array}{l}
f_{A}=-k_{5}\left(\sum_{r} \phi_{w r}\left(x_{A}\right) \xi_{r}-x_{e R}\right) \\
M_{A}=-k_{\theta 5}\left(\sum_{r} \phi_{\psi r}\left(x_{A}\right) \xi_{r}-\theta_{e R}\right)
\end{array}\right\}
$$

$k_{5}, k_{\theta 5}$ はそれぞれ点 $\mathrm{A}$ で弾性梁と剛体リンクを結合しているバネの並進バネ剛性，回転バネ剛性であり， $x_{A}$ は 弾性梁の軸方向に $x$ 軸をとった座標系における点 $\mathrm{A}$ の位置である.

モーダル座標系における弾性梁への点 A からの力の $r$ 次モードへの寄与 $f_{\xi r}^{A}$ は次式である.

$$
f_{\xi r}^{A}=f_{A} \phi_{w r}\left(x_{A}\right)+M_{A} \phi_{\psi r}\left(x_{A}\right)
$$

式(17)を式(18)に代入することにより次式が得られる.

$$
\mathbf{f}_{\xi}^{A}=-\mathbf{K}_{\xi}^{A} \boldsymbol{\xi}-\mathbf{K}_{\xi q}^{A} \mathbf{q}
$$


ここで,

$$
\begin{aligned}
& \mathbf{f}_{\xi}^{A}=\left\{f_{\xi 1}^{A} f_{\xi 2}^{A} \cdots f_{\xi r}^{A} \cdots\right\}^{T} \\
& K_{\xi i j}^{A}=k_{5} \phi_{w i}\left(x_{A}\right) \phi_{w j}\left(x_{A}\right)+k_{\theta 5} \phi_{\psi i}\left(x_{A}\right) \phi_{\psi j}\left(x_{A}\right) \\
& \mathbf{K}_{\xi q}^{A}=\left[\cdots-k_{5} \boldsymbol{\phi}_{w}^{A} \mathbf{0}-k_{\theta 5} \boldsymbol{\phi}_{\psi}^{A} \cdots\right] \\
& \boldsymbol{\phi}_{w}^{A}=\left\{\phi_{w 1}\left(x_{A}\right) \phi_{w 2}\left(x_{A}\right) \cdots \phi_{w r}\left(x_{A}\right) \cdots\right\}^{T} \\
& \boldsymbol{\phi}_{\psi}^{A}=\left\{\phi_{\psi 1}\left(x_{A}\right) \phi_{\psi 2}\left(x_{A}\right) \cdots \phi_{\psi r}\left(x_{A}\right) \cdots\right\}^{T}
\end{aligned}
$$

$\mathbf{K}_{\xi q}^{A}$ は, 点 $\mathrm{A}$ の剛体リンクの変位ベクトル $\mathbf{u}_{e R}$ に対応寸る部分の成分を表記しており，その他の成分は 0 である. 同様にすべての結合点（点 $\mathrm{B}, \mathrm{C} ， 1 ， 2 ， 3 ， 4 ）$ における反力を弾性梁のモーダル座標, 剛体リンクの座標で求め ることができる，点 $\mathrm{B}, \mathrm{C}$ における $\mathbf{K}_{\xi q}^{B}, \mathbf{K}_{\xi q}^{C}$ マトリクスにおいては，それぞれ $\mathbf{u}_{f R}, \mathbf{u}_{g R}$ に対応した部分の成分 となる。

弾性梁の運動方程式はモーダル座標系において, 剛体リンクとの結合点 $\mathrm{A}, \mathrm{B}, \mathrm{C}$ からの力の各モードへの寄与 $\mathbf{f}_{\xi}^{A}, \mathbf{f}_{\xi}^{B}, \mathbf{f}_{\xi}^{C}$ を用いて次式となる.

$$
\mathbf{\Omega}=\mathbf{f}_{\xi}^{A}+\mathbf{f}_{\xi}^{B}+\mathbf{f}_{\xi}^{C}
$$

ここで， $\boldsymbol{\Omega}$ はモーダル動岡性であり，その $r$ 行 $s$ 列成分 $\Omega_{r s}$ は以下である.

$$
\Omega_{r s}=\left\{\begin{array}{cr}
\mu_{r}\left(-\omega^{2}+j \omega \omega_{r} \eta_{r}+\omega_{r}^{2}\right) & , r=s \\
0 & , r \neq s
\end{array}\right.
$$

$\mu_{r}, \omega_{r}, \eta_{r}$ はそれぞれ $r$ 次モードのモーダル質量, 固有角振動数, モーダル減衰係数である.

リンク a の重心におけるリンク b， c， d との拘束は次のように表される.

$$
\left.\begin{array}{l}
\mathbf{u}_{a o}-\mathbf{u}_{b L}=\mathbf{0} \\
\mathbf{u}_{a o}-\mathbf{u}_{c L}=\mathbf{0} \\
\mathbf{u}_{a o}-\mathbf{u}_{d L}=\mathbf{0}
\end{array}\right\}
$$

式(23) を式 (23) の剛体リンクの変位ベクトル $\mathbf{q}$ に関するヤコビアンマトリクス $\mathbf{C}_{q}$ を用いて式 (24)のように表す.

$$
\mathbf{C}_{q} \mathbf{q}=\mathbf{0}
$$

剛体リンクの運動方程式は, 式 (24) の拘束による力をラグランジュ乗数 $\boldsymbol{\lambda}$ を用いて表すと次式のように表すこと ができる.

$$
\mathbf{D}_{q} \mathbf{q}+\mathbf{C}_{q}^{T} \boldsymbol{\lambda}=-\left(\mathbf{K}_{\xi q}^{A}{ }^{T}+\mathbf{K}_{\xi q}^{B}{ }^{T}+\mathbf{K}_{\xi q}^{C}{ }^{T}\right) \boldsymbol{\xi}+\mathbf{f}
$$

ここで $\mathbf{D}_{q}$ は弾性梁が運動していない場合（弾性梁を剛壁として考えた場合）の剛体リンクの動剛性マトリクスで あり, 結合点位置ベクトル $\mathbf{r}_{i}(i=2,3,4)$ の関数である. $\mathbf{K}_{\xi q}^{A}, \mathbf{K}_{\xi q}^{B}, \mathbf{K}_{\xi q}^{C}$ はそれぞれ弾性梁との結合点 $\mathrm{A}, \mathrm{B}, \mathrm{C}$ にお ける剛性マトリクスであり, 弾性梁のモード変位ベクトル $\boldsymbol{\xi}$ との積は弾性梁の変位により剛体リンクへ加わる力 を表す. f はバネ 1 によるリンク a の L 端への入力ベクトルである.

式(21)(24)(25) を連立することにより次式が導かれる.

$$
\begin{aligned}
& {\left[\begin{array}{ccc}
\boldsymbol{\Omega}+\mathbf{C}_{\xi} & \mathbf{C}_{\xi q} & \mathbf{0} \\
\mathbf{C}_{\xi q}^{T} & \mathbf{D}_{q} & \mathbf{C}_{q}^{T} \\
\mathbf{0} & \mathbf{C}_{q} & \mathbf{0}
\end{array}\right]\left\{\begin{array}{l}
\boldsymbol{\xi} \\
\mathbf{q} \\
\lambda
\end{array}\right\}=\left\{\begin{array}{l}
\mathbf{0} \\
\mathbf{f} \\
\mathbf{0}
\end{array}\right\}} \\
& \mathbf{C}_{\xi}=\mathbf{K}_{\xi}^{A}+\mathbf{K}_{\xi}^{B}+\mathbf{K}_{\xi}^{C} \\
& \mathbf{C}_{\xi q}=\mathbf{K}_{\xi q}^{A}+\mathbf{K}_{\xi q}^{B}+\mathbf{K}_{\xi q}^{C}
\end{aligned}
$$


$\mathbf{C}_{\xi}$ は剛体リンクが運動していない状態において, バネ 5 7 により弾性梁へ付加される動剛性を示しており, そ れぞれ式 (27) のように点 $\mathrm{A}$, 点 $\mathrm{B}$, 点 $\mathrm{C}$ の寄与に分かれる. $\mathrm{C}_{\xi q}$ は剛体リンクの運動がバネ 5〜7を介して弾性梁 へ及ぼす力の連成項であり， $\mathbf{C}_{\xi}$ と同様に各結合点からの寄与に分かれる.

式 (26) に式 (14) を代入し, 式 (26) の第 2 式の左から $\boldsymbol{\beta}^{T}$ をかけることにより剛体リンクの自由度が各剛体リン クの重心位置の自由度のみで表される。

$$
\begin{aligned}
& \mathbf{D x}=\mathbf{F} \\
& \left.\begin{array}{l}
\mathbf{D}=\left[\begin{array}{ccc}
\boldsymbol{\Omega}+\mathbf{C}_{\xi} & \mathbf{C}_{\xi q} \boldsymbol{\beta} & \mathbf{0} \\
\boldsymbol{\beta}^{T} \mathbf{C}_{\xi q}^{T} & \boldsymbol{\beta}^{T} \mathbf{D}_{q} \boldsymbol{\beta} \boldsymbol{\beta}^{T} \mathbf{C}_{q}^{T} \\
\mathbf{0} & \mathbf{C}_{q} \boldsymbol{\beta} & \mathbf{0}
\end{array}\right] \\
\mathbf{x}=\left\{\boldsymbol{\xi}^{T} \mathbf{q}_{o}^{T} \boldsymbol{\lambda}^{T}\right\}^{T} \\
\mathbf{F}=\left\{\mathbf{0}\left(\boldsymbol{\beta}^{T} \mathbf{f}\right)^{T} \mathbf{0}\right\}^{T}
\end{array}\right\}
\end{aligned}
$$

\section{$3 \cdot 3$ 弾性梁への入カパワー}

弾性梁への入力パワー $P$ は, 弾性梁と剛体リンクの結合点 $\mathrm{A}, \mathrm{B}, \mathrm{C}$ からの入力パワーの和として次式のように 表される.

$$
\begin{aligned}
& P=P^{A}+P^{B}+P^{C} \\
& P^{k}=\operatorname{Re}\left\{\frac{-j \omega}{2}\left(f_{k} w^{*}\left(x_{k}\right)+M_{k} \psi^{*}\left(x_{k}\right)\right)\right\}, \quad k=A, B, C
\end{aligned}
$$

ここで, $f_{B}, M_{B}, f_{C}, M_{C}$ は式 (17) で示した $f_{A}, M_{A}$ と同様に, それぞれ並進バネ, 回転バネから弾性梁の B 点, C 点にかかる力, モーメントである. 式(31)を弾性梁のモーダル座標系で表し, 式(19)(27)(28)などを用いて展開 すると次のようになる.

$$
P=\operatorname{Re}\left\{\frac{j \omega}{2}\left(\boldsymbol{\xi}^{H} \mathbf{C}_{\xi} \boldsymbol{\xi}+\boldsymbol{\xi}^{H} \mathbf{C}_{\xi q} \mathbf{q}\right)\right\}
$$

上付き $H$ は共役転置を示寸. 式 (26)の第 1 式より以下の関係がある.

$$
\mathbf{C}_{\xi q} \mathbf{q}=-\left(\mathbf{\Omega}+\mathbf{C}_{\xi}\right) \boldsymbol{\xi}
$$

式(33)に式(34)を代入すると最終的に次のように表される.

$$
\begin{aligned}
& P=\boldsymbol{\xi}^{H} \mathbf{R} \boldsymbol{\xi} \\
& \mathbf{R}=\operatorname{Re}\left\{\frac{-j \omega}{2} \boldsymbol{\Omega}\right\}
\end{aligned}
$$

式(35) は, 弾性梁での散逸パワーを示しており, 式(33) と式(35) が等しいことは, 入力パワーと散逸パワーが等 しくなることを表している.

\section{4 入カパワーの感度}

剛体リンクから弾性梁への入力パワーを低減することを考える. 加振力の大きさや位相を任意に選べる場合は, 2 次形式で表された入力パワーを固有值解析することにより入力パワーの入る効率が低い加振分布を求めることが できる（Alfredsson，1997）。しかし，サスペンションのような分系の運動により加振分布が決まる系においては， 任意に加振分布を設定することは難しい，そこで，本論文では，剛体リンク結合点位置に関する入力パワーの感 度解析を用いて形状最適化を行い入力パワーを低減することを考える.

結合点の位置ベクトル $\mathbf{r}_{i}(i=2,3,4)$ の $X, Y$ 方向成分を設計変数 $\gamma$ とする. 入力パワー $P$ の設計変数 $\gamma$ に対する 一次感度は次式となる。

$$
\frac{\partial P}{\partial \gamma}=2 \operatorname{Re}\left\{\frac{\partial \boldsymbol{\xi}^{H}}{\partial \gamma} \mathbf{R} \boldsymbol{\xi}\right\}+\boldsymbol{\xi}^{H} \frac{\partial \mathbf{R}}{\partial \gamma} \boldsymbol{\xi}
$$


式 (36) の $\mathbf{R}$ は弾性梁のモーダルパラメータに関する関数であり, $\gamma$ の関数でないので, 右辺第 2 項は 0 となる. $\partial \boldsymbol{\xi} / \partial \gamma$ は運動方程式 (29) を $\gamma$ に関して微分することにより求められる $\partial \mathbf{x} / \partial \gamma$ の一部である.

$$
\frac{\partial \mathbf{x}}{\partial \gamma}=-\mathbf{D}^{-1} \frac{\partial \mathbf{D}}{\partial \gamma} \mathbf{x}+\mathbf{D}^{-1} \frac{\partial \mathbf{F}}{\partial \gamma}
$$

上式の右辺第 2 項の $\mathbf{F}$ は, 式(30) で示すように, 式(15) で示した各剛体リンクの両端の変位と重心の変位の関係 を表した $\boldsymbol{\beta}$ マトリクスの関数であるので設計変数 $\gamma$ の関数であるが，検討を行うモデルでは外力ベクトル $\mathbf{f}$ のか かる部分は $\boldsymbol{\beta}$ マトリクス中の $\boldsymbol{\beta}_{a}$ に対応し， $\boldsymbol{\beta}_{a}$ は設計変数 $\gamma$ の関数でないため $\mathbf{0}$ となる. 右辺第 1 項の $\partial \mathbf{D} / \partial \gamma$ は, $\boldsymbol{\beta}, \mathbf{D}_{q}$ が設計変数 $\gamma$ の関数であるので次のようになる.

$$
\frac{\partial \mathbf{D}}{\partial \gamma}=\left[\begin{array}{ccc}
\mathbf{0} & \mathbf{C}_{\xi q} \frac{\partial \boldsymbol{\beta}}{\partial \gamma} & \mathbf{0} \\
\frac{\partial \boldsymbol{\beta}^{T}}{\partial \gamma} \mathbf{C}_{\xi q}^{T} \frac{\partial \boldsymbol{\beta}^{T}}{\partial \gamma} \mathbf{D}_{q} \boldsymbol{\beta}+\boldsymbol{\beta}^{T} \frac{\partial \mathbf{D}_{q}}{\partial \gamma} \boldsymbol{\beta}+\boldsymbol{\beta} \mathbf{D}_{q} \frac{\partial \boldsymbol{\beta}}{\partial \gamma} \frac{\partial \boldsymbol{\beta}^{T}}{\partial \gamma} \mathbf{C}_{q}^{T} \\
\mathbf{0} & \mathbf{C}_{q} \frac{\partial \boldsymbol{\beta}}{\partial \gamma} & \mathbf{0}
\end{array}\right]
$$

\section{$3 \cdot 5$ 弾性梁への入カパワーのクロスモード展開}

エネルギーフローの変化を固有モードの観点より考察するために，剛体リンク，弾性梁からなる全系の固有モー ドを考え，入力パワーを全系の固有モードに関して展開する.

\subsection{1 固有值解析}

拘束を含む系の固有值分解は池澤らの手法に習う (池澤, 吉村, 2008). 運動方程式 (29)(30)において $\boldsymbol{\beta}^{T} \mathbf{C}_{q}^{T}$ を $\mathrm{QR}$ 分解する.

$$
\boldsymbol{\beta}^{T} \mathbf{C}_{q}^{T}=\left[\begin{array}{ll}
\mathbf{Q}_{1} & \mathbf{Q}_{2}
\end{array}\right]\left[\begin{array}{c}
\mathbf{R}_{1} \\
\mathbf{0}
\end{array}\right]=\mathbf{Q}_{1} \mathbf{R}_{1}
$$

剛体リンクの変位ベクトル $\mathbf{q}_{o}$ を以下のように拘束力に直交した剛体リンクの変位ベクトル $\hat{\mathbf{q}}_{o}$ で表す.

$$
\mathbf{q}_{o}=\mathbf{Q}_{2} \hat{\mathbf{q}}_{o}
$$

式(41)を運動方程式 (29)(30) に代入し，第 2 式の左から $\mathbf{Q}_{2}^{T}$ をかけると次式が導かれる.

$$
\begin{aligned}
\hat{\mathbf{D}} \hat{\mathbf{x}} & =\hat{\mathbf{F}} \\
\hat{\mathbf{D}} & =\left[\begin{array}{cc}
\boldsymbol{\Omega}+\mathbf{C}_{\xi} & \mathbf{C}_{\xi q} \boldsymbol{\beta} \mathbf{Q}_{2} \\
\mathbf{Q}_{2}^{T} \boldsymbol{\beta}^{T} \boldsymbol{C}_{\xi q}^{T} \mathbf{Q}_{2}^{T} \boldsymbol{\beta}^{T} \mathbf{D}_{q} \boldsymbol{\beta} \mathbf{Q}_{2}
\end{array}\right] \\
\hat{\mathbf{x}} & =\left\{\boldsymbol{\xi}^{T} \hat{\mathbf{q}}_{o}^{T}\right\}^{T} \\
\hat{\mathbf{F}} & =\left\{\mathbf{0}\left(\mathbf{Q}_{2}^{T} \boldsymbol{\beta}^{T} \mathbf{f}\right)^{T}\right\}^{T}
\end{aligned}
$$

式(42) は次のように慣性項，減衰項，剛性項に分けて表すことができる.

$$
\left(-\omega^{2} \hat{\mathbf{D}}_{M}+j \omega \hat{\mathbf{D}}_{C}+\hat{\mathbf{D}}_{K}\right) \hat{\mathbf{x}}=\hat{\mathbf{F}}
$$

上式の $j \omega \hat{\mathbf{D}}_{C}$ を省略することにより実固有值解析が可能となり，その実固有べクトルを並べたモードマトリクス

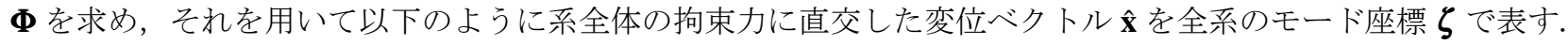

$$
\hat{\mathbf{x}}=\Phi \zeta
$$

式(41), 式(43)の第 2 式と式(45)より, 変位ベクトル $\left\{\boldsymbol{\xi}^{T} \mathbf{q}_{o}^{T}\right\}^{T}$ は全系のモード座標 $\zeta$ で次のように表される.

$$
\begin{aligned}
\left\{\begin{array}{c}
\boldsymbol{\xi} \\
\mathbf{q}_{o}
\end{array}\right\} & =\left[\begin{array}{ll}
\mathbf{I} & \mathbf{0} \\
\mathbf{0} & \mathbf{Q}_{2}
\end{array}\right] \boldsymbol{\Phi} \boldsymbol{\zeta} \\
& =\left[\begin{array}{c}
\boldsymbol{\varphi}_{\xi} \\
\boldsymbol{\varphi}_{q_{o}}
\end{array}\right] \boldsymbol{\zeta}
\end{aligned}
$$




$$
\left.\begin{array}{l}
\boldsymbol{\varphi}_{\xi}=\left[\begin{array}{ll}
\mathbf{I} \mathbf{0}
\end{array}\right] \boldsymbol{\Phi} \\
\boldsymbol{\varphi}_{q_{o}}=\left[\begin{array}{ll}
\mathbf{0} & \mathbf{Q}_{2}
\end{array}\right] \boldsymbol{\Phi}
\end{array}\right\}
$$

\subsection{2 クロスモード展開}

式(33)で表された入力パワーへ式(14)(46) を代入すると次式が導かれる.

$$
\begin{aligned}
& P=\operatorname{Re}\left\{\frac{j \omega}{2} \boldsymbol{\zeta}^{H} \boldsymbol{\Psi} \zeta\right\} \\
& \boldsymbol{\Psi}=\boldsymbol{\varphi}_{\xi}^{T} \mathbf{C}_{\xi} \boldsymbol{\varphi}_{\xi}+\boldsymbol{\varphi}_{\xi}^{T} \mathbf{C}_{\xi q} \boldsymbol{\beta} \boldsymbol{\varphi}_{q_{o}}
\end{aligned}
$$

$r$ 次モードのモード振幅 $\zeta_{r}$ と $s$ 次モードのモード振幅 $\zeta_{s}$ には $\operatorname{Im}\left\{\zeta_{r} \zeta_{s}^{*}\right\}=-\operatorname{Im}\left\{\zeta_{s} \zeta_{r}^{*}\right\}$ の関係があり, $\Psi$ が実数マ トリクスであることより, 式 (48) は振動インテンシティのモード展開（山崎, 2007）と同様に $r$ 次モードと $s$ 次 モードの組み合わせの線形和として以下のように展開される。

$$
\begin{aligned}
& P=\sum_{r=1}^{n-1} \sum_{s=r+1}^{n} \alpha_{r s} \operatorname{Im}\left\{\zeta_{r} \zeta_{s}^{*}\right\} \\
& \alpha_{r s}=\frac{\omega}{2}\left(\Psi_{r s}-\Psi_{s r}\right)
\end{aligned}
$$

ここで, $n$ は全系のモード座標 $\zeta$ーモド数, $\Psi_{r s}$ は $\boldsymbol{\Psi}$ マトリクスの $r$ 行 $s$ 列成分である. それぞれ $\alpha_{r s}$ を $(r, s)$ 次 クロスモード係数, $\operatorname{Im}\left\{\zeta_{r} \zeta_{s}^{*}\right\}$ を $(r, s)$ 次クロスモード振幅と呼ぶこととする.

\section{4. 解 析 結 果}

\section{1 形状最適化結果}

入力パワーの感度を用いて剛体リンクの形状の最適化を行う。最適化手法は MMA を用いた（Krister, 1987）. 設計変数は結合点の位置ベクトル $\mathbf{r}_{i}(i=2,3,4)$ の $X, Y$ 成分の 6 変数とし, 設計変数の範囲をそれぞれ初期位置か ら $\pm 25[\mathrm{~mm}]$ とした。 目的関数 $J$ は次式で表される低減したい周波数範囲における入力パワーの積分值とする.

$$
J=\int_{f_{1}}^{f_{2}} P d f
$$

周波数の積分範囲は，初期配置において大きなピークが確認された $100 \mathrm{~Hz} \sim 200 \mathrm{~Hz}$ とした.

図 2 に初期配置と設計変数の範囲, 最適化後の配置を示す. 図 3(a) に式 (53) で表される強制変位による系全体 への入力パワー $P_{s y s}$ を示し, 図3(b)に弾性梁への入力パワーを示す.

$$
P_{s y s}=\operatorname{Re}\left\{\frac{-j \omega}{2}\left\{-k_{1}\left(u_{a L}-w_{0}\right)-j \omega c\left(u_{a L}-w_{0}\right)\right\} w_{0}^{*}\right\}
$$

図3(a) の系全体への入力パワーにおいては，それぞれの配置における入力パワーの大きさはほとんど変わらな い. しかし, 図 3(b) の弾性梁への入力パワーにおいては, 最適化対象周波数帯のピーク周波数（特に $117 \mathrm{~Hz}$ のピー ク）において, 大きな低減が確認できる. これは, 剛体リンクの運動が変わり, 弾性梁へエネルギーが流れないエ ネルギーフローとなったことを表している.

\section{$4 \cdot 2$ 各結合点からの寄与}

初期配置と最適配置におけるエネルギーフローを確認するために，弾性梁と剛体リンクの各結合点（A,B,C）に おける弾性梁への正の入力パワーと負の入力パワーの寄与を次式で示す正規化した入力パワーを用いて表す.

$$
\left.\begin{array}{l}
P_{n o r}^{k}=\frac{P^{k}}{\left|P^{A}\right|+\left|P^{B}\right|+\left|P^{C}\right|}, \quad(k=A, B, C) \\
P_{n o r}^{t o t}=P_{n o r}^{A}+P_{n o r}^{B}+P_{n o r}^{C}
\end{array}\right\}
$$

$P_{\text {nor }}^{\text {tot }}$ は，全ての点で正の入力パワーが入っていれば 1 となる. 初期配置と最適配置の正規化した入力パワーを図 4 に示す. 正規化した入力パワーが負の值となっている周波数帯（初期位置における $150 \mathrm{~Hz}$ 以下の点 A からの入力 


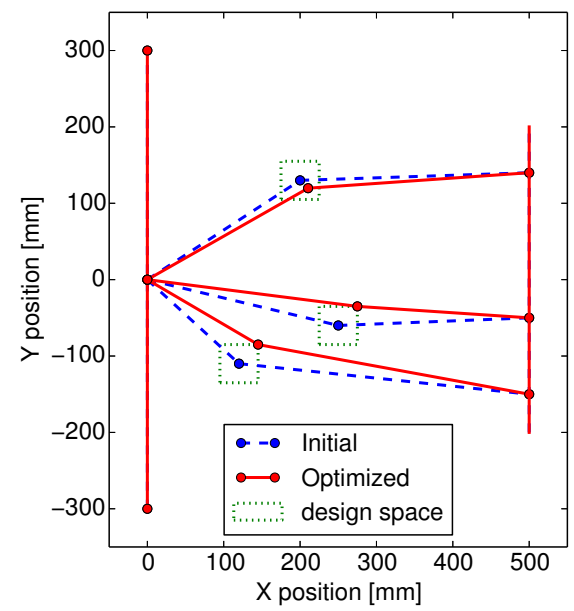

Fig. 2 Optimization results. Initial configuration (blue dashed), optimized configuration (red solid) and design space (green dotted)

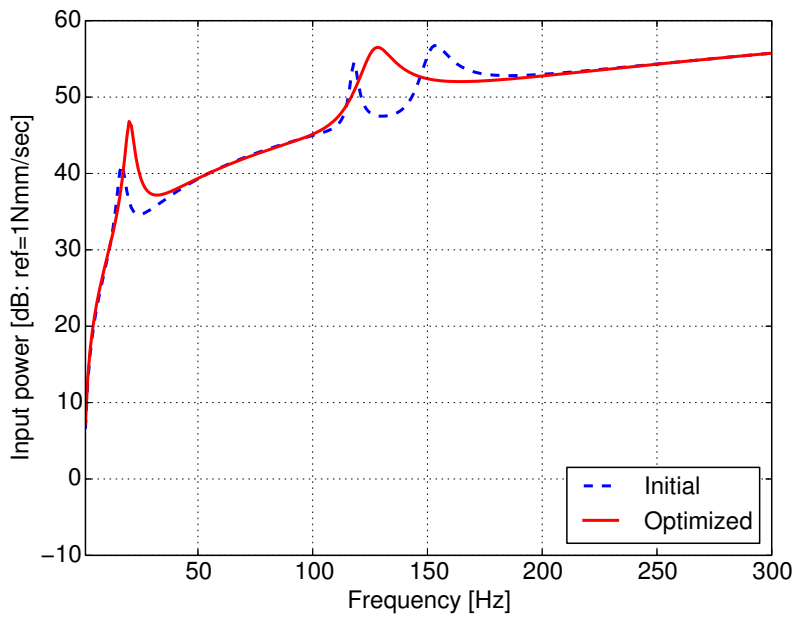

(a) Input power to the system

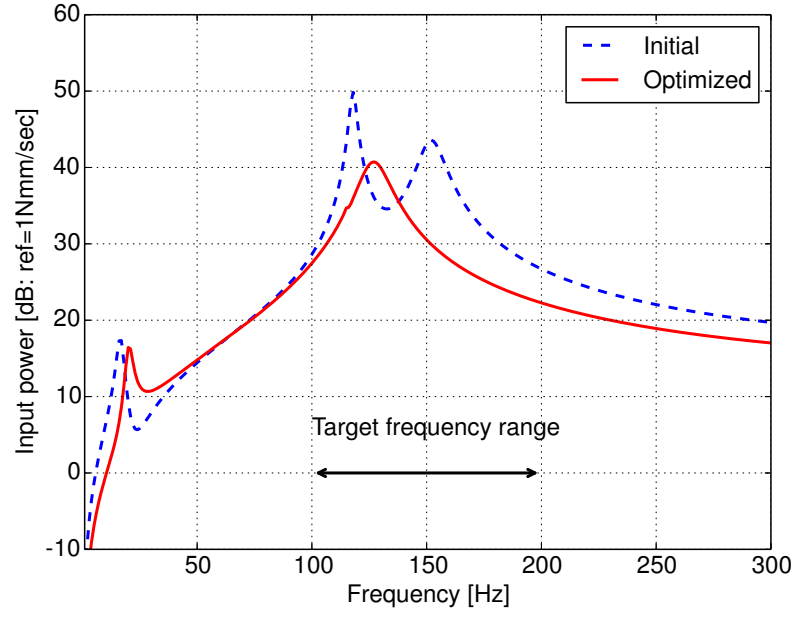

(b) Input power to the elastic beam

Fig. 3 Optimization results. (a) Input power to the system in the case of the initial configuration (blue dashed), the case of the optimized configuration (red solid). (b) Input power to the elastic beam in the case of the initial configuration (blue dashed), the case of the optimized configuration (red solid).

など）は，その点の梁の振動速度方向とリンクからの加振方向が逆となり，その点で梁のエネルギーが散逸して いることを示している.

図 3(b) において大きな低減効果が確認できた対象周波数帯の低周波数側のピーク (初期配置における $117 \mathrm{~Hz}$, 最 適配置における $115 \mathrm{~Hz}$ のピーク)に着目寸る. 図 4 より，これらのピーク周波数においては，正の入力パワーと なる結合点と負の入力パワーとなる結合点が存在し, 初期配置では, それらの正規化された入力パワーのトータ ルは 0.25 程度であるのに対し，最適配置においては，正規化された入力パワーのトータルが 0 に近くなっている. つまり，最適配置では，正の入力パワーと負の入力パワーの相殺による入力パワーの低減が起こっていることがわ かる.

\section{3 入カパワーの全系のモードに関するクロスモード展開による考察}

図 3(b) で大きな低減効果が確認できた 2 次共振周波数（初期配置の $117 \mathrm{~Hz}$ ，最適配置の $115 \mathrm{~Hz}$ ） と，最適化対 象周波数ではないが広い周波数帯で低減が確認できた $200 \mathrm{~Hz}$ 以上の高周波域の 2 つの周波数帯について 3.5 節で 


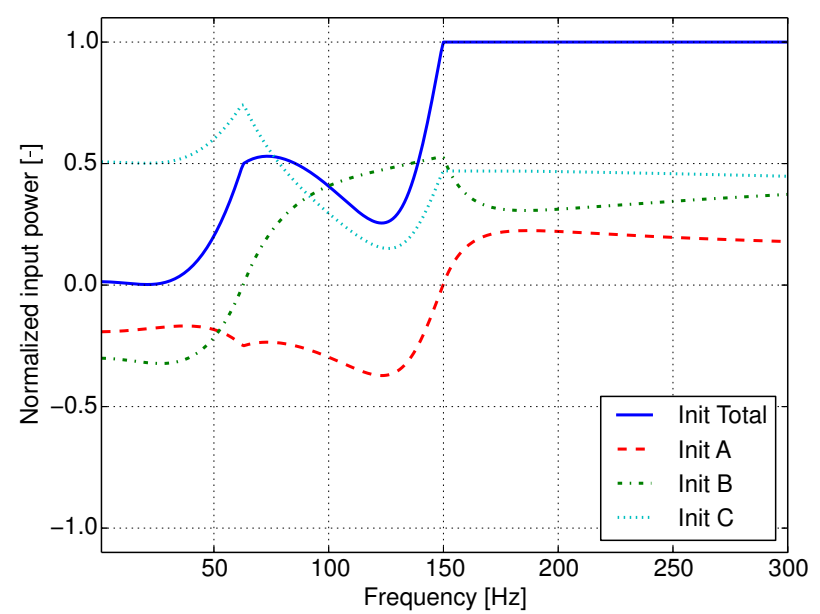

(a) Initial configuration

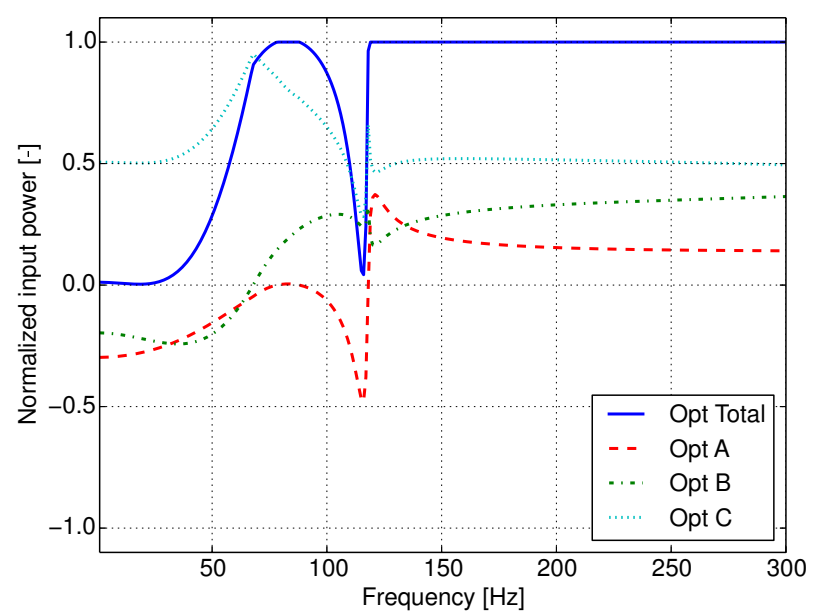

(b) Optimized configuration

Fig. 4 Normalized input power expressed in Eq.(54), (a) the case of initial configuration, (b) the case of optimized configuration. Total input power (blue solid), input power from the point A (red dashed), input power from the point B (green dash-dot), and input power from the point $\mathrm{C}$ (cyan dotted)

示したクロスモード展開を用いて考察を行う.

\subsection{1 剛体リンクの配置最適化による固有モードの変化}

初期配置における固有モード形状を図 5 に示し，最適配置における固有モード形状を図 6 に示す. 図 5 と図 6 の 比較より，最適化対象周波数帯に固有周波数を持つ 2 次モードのモード形状が大きく变化しているが，その他の モード形状はあまり変化していないことが確認できる.

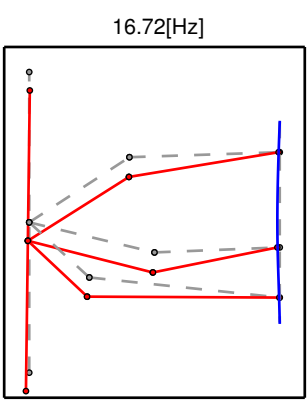

(a) 1 st mode

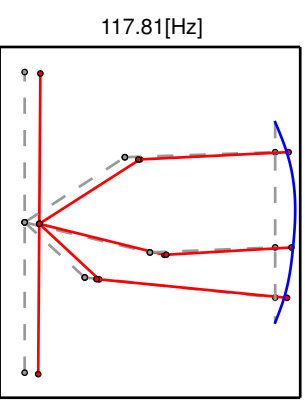

(b) 2nd mode

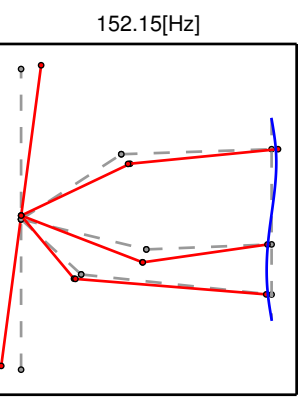

(c) 3rd mode

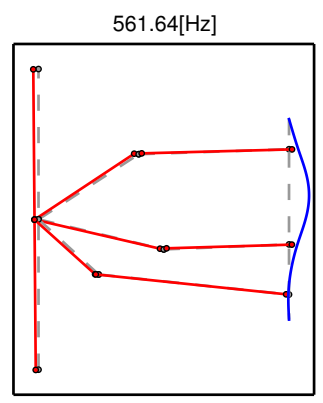

(d) 4th mode

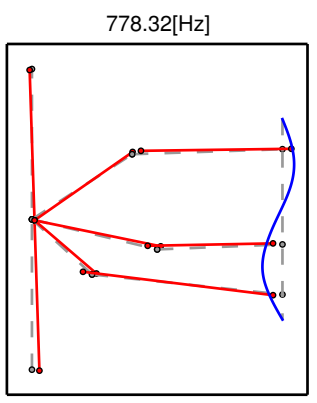

(e) 5 th mode

Fig. 5 Modeshape of the first 5 modes in the initial configuration: The configration (gray dashed), modeshape of rigid links (red sold) and elastic beam (blue solid). Modeshape is plotted by scaling the maximum displacement as $40[\mathrm{~mm}]$. Each natural frequency of the modes is written above the figures.

\subsubsection{2 次共振周波数のピークにおける入カパワーのクロスモード展開}

図 3(b) の最適化対象周波数帯の低周波数側の共振周波数におけるモード振幅 $\left|\zeta_{r}\right|$, クロスモード振幅 $\operatorname{Im}\left\{\zeta_{r} \zeta_{s}^{*}\right\}$, クロスモード入力パワーをそれぞれ初期配置の場合を図 7 に，最適配置の場合を図 8 に示す. モード振幅は 1 次 から 7 次，クロスモード振幅とクロスモード入力パワーはクロスモード入力パワーの大きい 7 つを選び表示する. 図 7(c), 図 8(c) のクロスモード入力パワーには, トータルのクロスモード入力パワーに加え, 各結合点 $\mathrm{A}, \mathrm{B}, \mathrm{C}$ からのクロスモード入力パワー成分も合わせて表示する.

初期配置の場合においては，図7(a)のように 2 次モードが大きく励起している．検討をしているような減衰が小 さい場合, クロスモード振幅は共振している 2 次モードとそれ以外のモードの位相差が $\pi / 2$ となることから，共 振している 2 次モードとのクロスモード振幅が大きくなる. 2 次モードの次に 3 次モードのモード振幅が大きいこ 


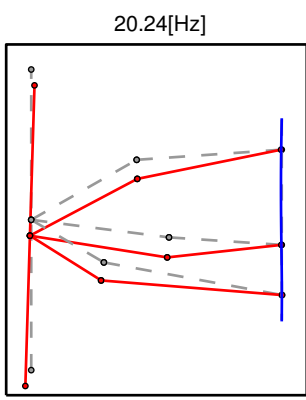

(a) 1 st mode

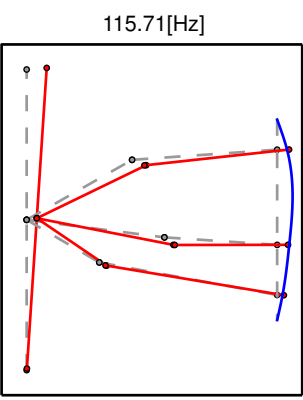

(b) 2nd mode

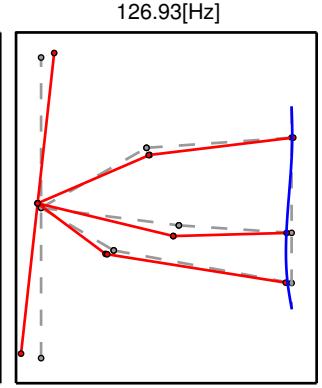

(c) 3rd mode

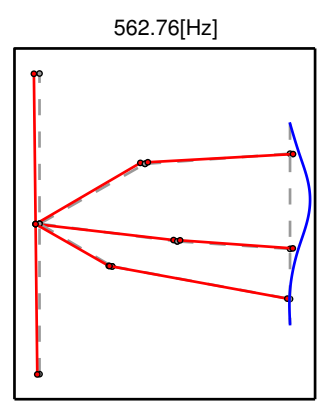

(d) 4th mode

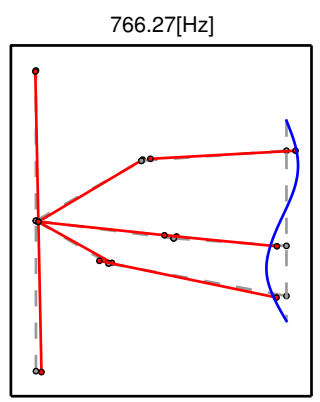

(e) 5 th mode

Fig. 6 Modeshape of the first 5 modes in the optimized configuration: The configration (gray dashed), modeshape of rigid links (red sold) and elastic beam (blue solid). Modeshape is plotted by scaling the maximum displacement as $40[\mathrm{~mm}]$. Each natural frequency of the modes is written above the figures.

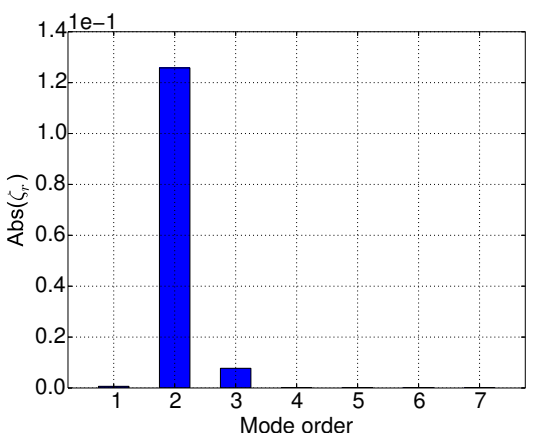

(a) Modal amplitude

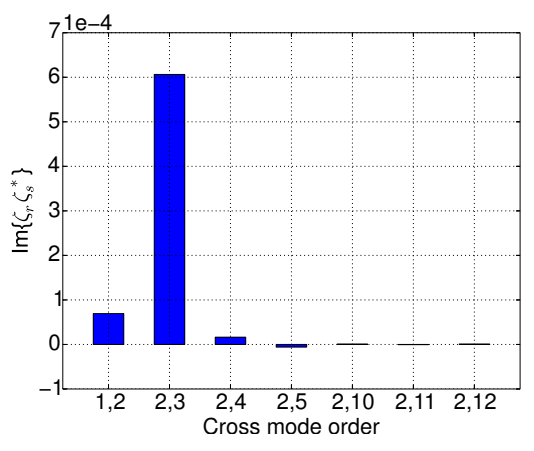

(b) Cross modal amplitude

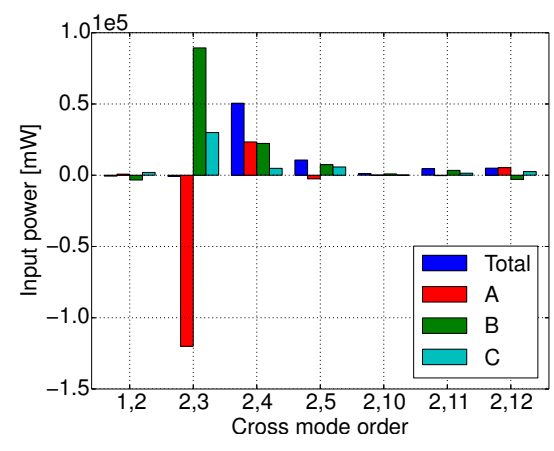

(c) Cross modal input power

Fig. 7 Modal component at 2nd peak in the initial configuration. (a) Modal amplitude. (b) Cross modal amplitude. (c) Cross modal input power. Total input power (blue), input power from the point A (red), input power from the point $\mathrm{B}$ (green) and input power from the point $\mathrm{C}$ (cyan)

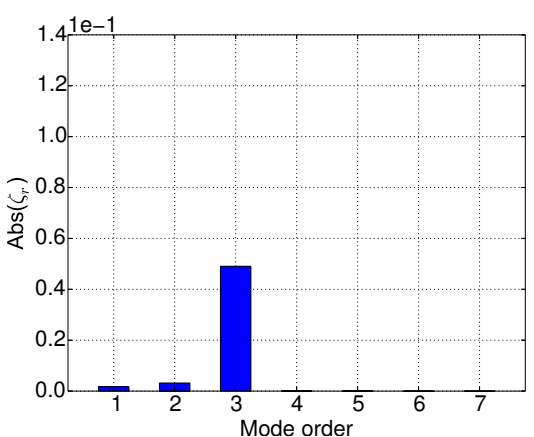

(a) Modal amplitude

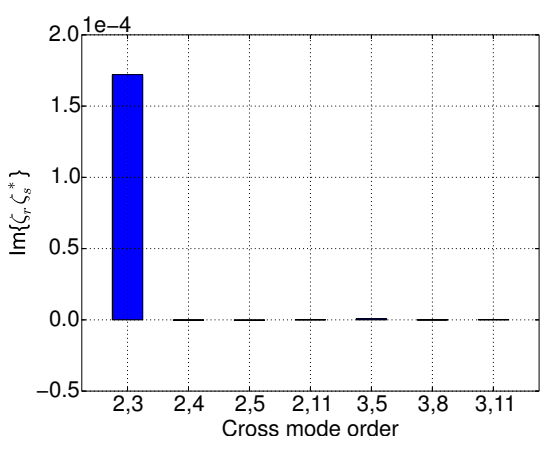

(b) Cross modal amplitude

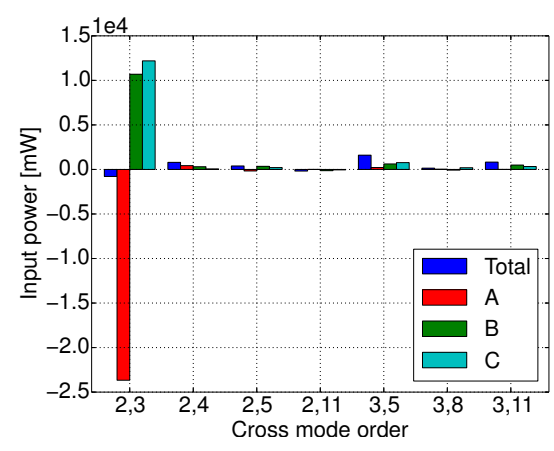

(c) Cross modal input power

Fig. 8 Modal component at 2nd peak in the optimized configuration. (a) Modal amplitude. (b) Cross modal amplitude. (c) Cross modal input power. Total input power (blue), input power from the point A (red), input power from the point $\mathrm{B}$ (green) and input power from the point $\mathrm{C}$ (cyan)

とから，(2,3) 次のクロスモード成分が大きくなっていることが図 7(b) より確認できる．しかしながら，図 7(c) の クロスモード入力パワーにおいては，(2,3) 次クロスモードの各取り付け点からの入力パワーが正と負で相殺する ため, $(2,3)$ 次クロスモードの総入力パワーは小さく, $(2,4)$ 次クロスモードの入力パワーが支配的な成分となって いる.

最適配置の場合においては，図 8(a) のように 2 次モードの共振周波数であるが， 3 次モードが 2 次モードより も大きく励起している。この 2 次モード振幅の減少は，図 6(b) のように，2 次モードのモード形状が加振点にお いて節を持つためである．2 次モード振幅が小さいことより，それに伴い，図 8(b) のように $(2,3)$ 次モード以外の 
2 次モードに関連したクロスモード振幅が小さくなり，それにより初期配置で支配的であった $(2,4)$ 次モードのク ロスモード入力パワーが小さくなっていることが図 8(c)より確認ができる.

また, 図 4 で確認された各結合点間の入力パワーの相殺は, 図 7(c), 図 8(c) より初期配置, 最適配置ともに主 に $(2,3)$ 次クロスモードのエネルギーフローによるものであることが分かる. 特に図 4(b) の最適配置において正規 化された入力パワーが 0 に近くなったことは，図 8(c) のように $(2,3)$ 次モード以外のクロスモード成分の寄与が小 さくなったためであることが分かる.

\subsection{3 最適化対象周波数帯より高周波側の入カパワーのクロスモード展開}

図 3(b) において, 最適化対象周波数ではないが, 最適配置において $200 \mathrm{~Hz}$ 以上の高周波域の入力パワーが低減 している. $250 \mathrm{~Hz}$ におけるクロスモードを確認することにより，その周波数帯で入力パワーが低減している理由を 確認する. 図 9 に $250 \mathrm{~Hz}$ における (a) モード振幅, (b) クロスモード振幅, (c) クロスモード入力パワーのそれぞれ 初期配置の場合と最適配置の場合を示す。モード振幅は 1 次から 7 次を, クロスモード振幅とクロスモード入力 パワーは, それぞれ初期配置, 最適配置においてクロスモード入力パワーの大きい7つを選び, その論理和（結 果として 8 個) を示す.

図 9(c) より, 初期配置, 最適配置ともに $(3,5)$ 次, $(3,11)$ 次クロスモード入力パワーが大きいことが分かる.ま た，初期配置においては，(2,5) 次，(2,11) 次クロスモード入力パワーも大きな成分を持っている.

まず，初期配置と最適配置の $(3,5)$ 次クロスモード入力パワーについて考える. 図 9(a)より，3 次，5次ともに 初期配置より最適配置の方が振幅が小さい. それに伴い, 図 9(b) において $(3,5)$ 次クロスモード振幅が小さくなっ ていることが確認できる。これにより $(3,5)$ 次クロスモード入力パワーが低減していることが分かる.

次に, $(2,5)$ 次および $(2,11)$ 次クロスモード入力パワーについて考える. 図 9(a) において, 最適配置における 2 次モード振幅が非常に小さくなっていることが確認できる．これは，前述のように，加振点が 2 次モードのモー ド形状の節となっているからである。そのため, 2 次モードが関連する $(2,5)$ 次, $(2,11)$ 次のクロスモード振幅が 小さくなる. その結果, $(2,5)$ 次, $(2,11)$ 次のクロスモード入力パワーがほぼ 0 になっている.

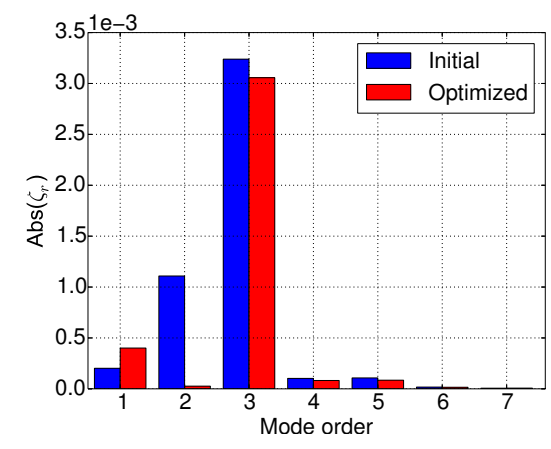

(a) Modal amplitude

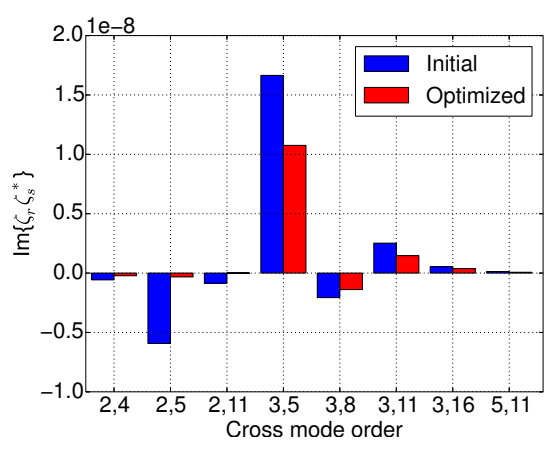

(b) Cross modal amplitude

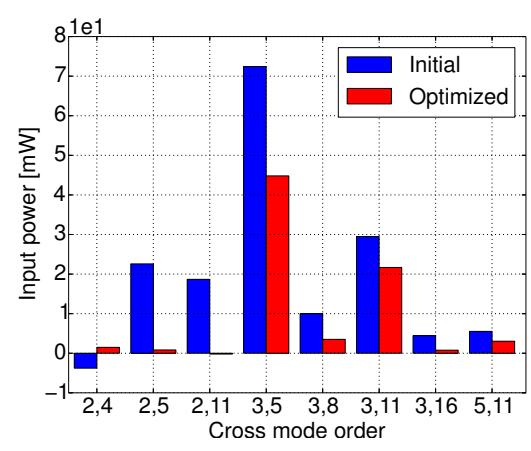

(c) Cross modal input power

Fig. 9 Comparison of modal componet at $250 \mathrm{~Hz}$. Initial configuration (blue) and optimized configuration (red). (a) Modal amplitude, (b) cross modal amplitude and (c) Cross modal input power.

\section{5. 結言}

本研究により以下の結論を得た.

1. サスペンションを想定した剛体リンクと多点で結合する弾性梁のモデルにおいて, 剛体リンクの配置を適正 化することにより系のエネルギーフローを変え, 弾性梁への入力パワーを低減できることを感度解析に基づ く形状最適化により示した。 また，入力パワーが低減した剛体リンク配置のエネルギーフローは，弾性梁の 各結合点からの入力パワーが正と負で相殺するエネルギーフローであることが分かった.

2. 系の固有モードに関する入力パワーのクロスモード展開により, エネルギーフローの変化をモード解析の観 点から考察した. 各結合点からの入力パワーが正と負で相殺するクロスモード成分が存在し，そのクロスモー 
ド成分が支配的となるような固有モードとなることで入力パワーが低減していることが分かった．

3. 入力パワーのクロスモード展開より，特定の固有モードを励起しづらくすることは，関連するクロスモードの 大きさが下がるため，共振周波数以外の周波数帯においても入力パワー低減に寄与することを明らかにした. 本研究において行った形状最適化による入力パワー低減手法は，最適化問題において操縦安定性に関する評価 を制限值とすることで, 静肃性と操縦安定性を両立したサスペンション構造の設計に用いることが可能であると 考えられ，その実現を今後検討していく.

\section{文献}

Alfredsson, K. S., Active and reactive structural energy flow, Journal of Vibration and Acoustics, Vol. 119 (1997), pp. $70-79$.

池澤 知徳, 吉村 卓也, MBD と感度解析を用いた自動車用サスペンションの振動特性最適化, 日本機械学会論文 集 C 編，Vol. 74, No. 740 (2008), pp. 897-903.

門松 晃司，岩永 良久，車体音響感度と加振点コンダクタンスの考察，日本機械学会論文集 C 編，Vol. 68, No. 676 (2002), pp. 3561-3565.

城戸一郎, 未岡 淳男, 2 つの分系が強く連成する振動系の解析法（第 1 報, 自動車サスペンションヘの適用）, 日 本機械学会論文集 C 編, Vol. 71, No. 712 (2005), pp. 3335-3342.

Krister, S., The method of moving asymptotes - a new method for structural optimization, International Journal for Numerical Methods in Engineering, Vol. 24 (1987), pp. 359-373.

山崎 徹, はりの曲げ振動インテンシティのモード展開, 日本機械学会論文集 C 編, Vol. 73, No. 731 (2007), pp. 1948-1954.

\section{References}

Alfredsson, K. S., Active and reactive structural energy flow, Journal of Vibration and Acoustics, Vol. 119 (1997), pp. $70-79$.

Ikezawa, T. and Yoshimura, T., Optimization of vibration properties of vehicle suspension systems by using MBD and sensitivity analysis (Application to eigen value optimization problem), Transactions of the JSME, Series C, Vol. 74, No. 740 (2008), pp. 897-903 (in Japanese).

Kadomatsu, K. and Iwanaga, Y., Vibro-acoustic transfer function and driving-point conductance for vehicle body, Transactions of the JSME, Series C, Vol. 68, No. 676 (2002), pp. 3561-3565 (in Japanese).

Kido, I. and Sueoka, A., Analytical approach for strongly coupled vibration system composed of two substructures (1st report, theory and its application to vibration of vehicle suspension), Transactions of the JSME, Series C, Vol. 71, No. 712 (2005), pp. 3335-3342 (in Japanese).

Krister, S., The method of moving asymptotes - a new method for structural optimization, International Journal for Numerical Methods in Engineering, Vol. 24 (1987), pp. 359-373.

Yamazaki, T., Modal expansion of structural intensity for flexural vibration on beams, Transactions of the JSME, Series C, Vol. 73, No. 731 (2007), pp. 1948-1954 (in Japanese). 